ISSN 0258-7122 (Print), 2408-8293 (Online)

Bangladesh J. Agril. Res. 43(2): 345-360, June 2018

\title{
IMPACTS OF WHEAT SEED STORAGE AT POOR HOUSEHOLD LEVEL IN BANGLADESH
}

\author{
M. A. MONAYEM MIAH ${ }^{1}$, Q. M. S. ISLAM ${ }^{2}$, M. E. BAKSH ${ }^{3}$ \\ F. J. ROSSI ${ }^{4}$ AND T. P. TIWARI ${ }^{5}$
}

\begin{abstract}
Small and marginal farmers have little access to improved seed from institutional sources and are thus largely excluded from the benefits of new varieties. The production and storage of improved varieties seeds at the household $(\mathrm{HH})$ level can successfully overcome this problem. With this aim CSISA-CIMMYT (Cereal Systems Initiative for South Asia) project in Bangladesh have been working since 2012. Therefore, the study assessed the impacts of wheat seed storage systems at $\mathrm{HH}$ level, with a particular emphasis on how the poor farmers are benefited by doing the seed storage business. The study analyzed data and information collected at random from 210 supported and 60 non-supported farmers spread over three wheat growing districts namely Mymensingh, Faridpur and Rangpur. Wheat farmers used different storage containers and showed the highest level of satisfaction towards plastic sac along with poly bags and plastic/metal drum due to cost effectiveness and seed quality maintenance. On an average, supported and non-supported farmers retained respectively $103 \mathrm{~kg}$ and $100 \mathrm{~kg}$ of seed at household level, and sold most of their seeds to neighbouring farmers, local markets, and dealers. Wheat seed storage at household level was a profitable business to most of the respondent farmers. They could earn a reasonable net income (Tk.1127-Tk.1210) from seed storage. The farmers who stored seed in plastic/metal drum received the highest net income due to higher storage capacity, less storage cost, and higher seed price. The wheat storage program has created significant impacts in the study areas. A substantial increase was recorded in wheat area, wheat productivity, and financial benefit of the wheat farmers as a whole. Nevertheless, improved wheat seed is now available at farm level and most farmers become enthusiastic towards improved wheat cultivation because of this program. Respondent farmers did not face any critical problem during seed storage.
\end{abstract}

\section{Introduction}

Wheat is one of the important cereal crops after rice in Bangladesh. It is highly nutritious and a good source of energy. It has versatile uses and a very good substitute of rice. The per capita wheat consumption increased to 26.09 gram/day in 2010 from 12.08 gram/day in 2005 at the national level (HIES, 2010). Rice self-sufficiency in Bangladesh is always fraught with uncertainty as the country suffers from different natural calamities. Therefore, to keep pace with the future demand of the growing population, the current production and

\footnotetext{
${ }^{1 \& 2}$ Agricultural Economics Division, Bangladesh Agricultural Research Institute (BARI), Gazipur and ${ }^{3,4 \& 5}$ CIMMYT Bangladesh.
} 
productivity of wheat must be raised for maintaining the country's food security without substantial and unaffordable imports.

The area and production of wheat continuously fluctuated over the years due to various reasons. Its production got a new momentum in the mid '90s and continued up to 1999. During this period, the area, production and yield of wheat registered positive and highly significant growth rates due to introduction of modern seed-water-fertilizer technologies (Miah et al., 2015). Unfortunately, both area and production started decreasing at a faster rate from 2000 and continued up to 2007 (Fig.1). Many wheat growers started shifting their wheat lands to Boro rice during this period because of stable and higher yield, higher return and for food security (Hussain and Iqbal, 2011). Besides, a vast wheat area was also replaced by maize in this period (Miah et al., 2013).

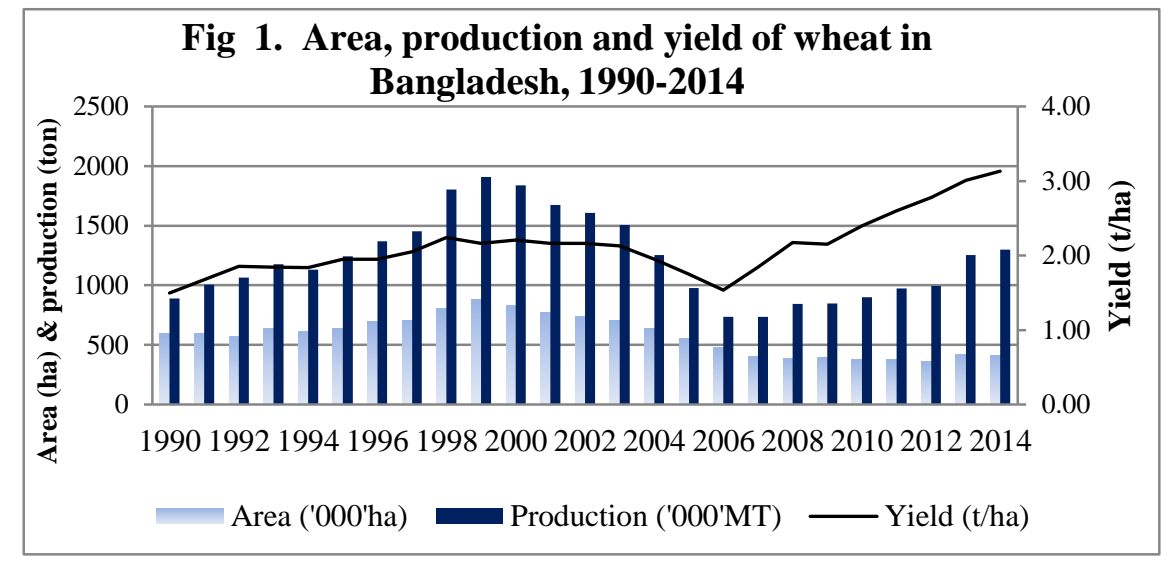

Source: BBS, 2011\& 2013; www.indexmundi.com (for year 2014)

Considering these depressing situations, Bangladesh Government give due emphasis to increase wheat production throughout the country as a source of sustaining food security. The scientists of Wheat Research Centre (WRC) have developed a number of improved wheat varieties that can tolerate saline soils and temperature elevation at seed-setting, as well as resisting new diseases through on-going selections from diverse germplasm provided by CIMMYT. Generally, the seeds of these improved varieties are multiplied and distributed by the Bangladesh Agricultural Development Corporation (BADC). At present, BADC produces 27,208 tons of wheat seed which is $48.4 \%$ of the total seed requirement (Maswood, 2014; Nuruzzaman, 2015). Much of these seeds were sourced by 'better-off' farmers following their attendance at demonstrations that are regularly promoted by the extension services of DAE and research organization (especially WRC, BARI and under different research projects).

Seed security is the key to the attainment of household food security among resource poor farmers in developing countries (Wambugu et al., 2009). Food insecure, marginal, and landless farmers have little access to these improved seed 
from BADC and are thus largely excluded from the benefits of any new variety (Page, 2007). The production and storage of improved varieties of seed at the household $(\mathrm{HH})$ level has successfully overcome this problem. Over the past three years, CIMMYT under the Cereal Systems Initiative for South Asia in Bangladesh (CSISA-BD) project activities has facilitated the dissemination of the new wheat varieties through seed production and storage trainings, as well as, onfarm trials and demonstrations among small and marginal wheat farmers. Additional supporting activities (e.g. farmer field days, market linkage workshops) were also conducted after wheat cultivation with the aim of encouraging farmers to store seeds of these new varieties at their $\mathrm{HH}$ level for own use and earning income by selling surplus portion. This 'bottom-up' seed dissemination program has created a lot of socioeconomic impacts at farm level that need to be documented properly. Therefore, the present study was conducted with the following objectives:

1. To find out the project supports and catalog the systems used in storing wheat seed at the $\mathrm{HH}$ level.

2. To assess the overall impacts of CSISA-CIMMYT wheat seed storage and dissemination program in the study areas.

\section{Methodology}

Sampling procedure and sample size: The study was conducted at three wheat growing districts, namely Mymensingh, Faridpur and Dinajpur. The populations of this study were the wheat farmers who stored wheat seed at their homes with the purpose of own use as well as business. Before selecting sample respondents, a list of wheat seed storing farmers was prepared with the help of CSISACIMMYT project personnel working under respective district. Finally, a total of 210 small and marginal (having land size 0.50-2.49 acres) supported farmers* taking 70 farmers from each districts were selected randomly for interview. Again, 60 small and marginal non-supported farmers (20 from each district) were also selected randomly as control. Thus the total sample size of the present study was 270 .

Method of data collection and period of study: Data for the present study were gathered from both primary and secondary sources. Primary data were collected from selected farmers with the aid of a pre-tested interview schedule during February-April, 2015. CSISA-CIMMYT project personnel in respective district assisted researchers and enumerators in collecting primary level data. Secondary data were collected from different published sources, such as BBS, journal articles, and internet.

Analytical technique: The collected data were edited and tabulated for analysis. Descriptive statistics were mostly used in analysing collected data and

\footnotetext{
* Supported poor farmers were those wheat farmers who took supports like seed storage training and improved wheat seed from CSISA-CIMMYT project.
} 
information. The cost of storage included the annual cost of container and protection measures. Due to very small number of samples, protection cost was not considered to calculate net income from storage. The annual cost of a container was calculated by applying straight-line method for one year. In this study, the salvage value of storage container was reported to be zero. Therefore, the straight-line equation applied in this study was as follows:

$$
\text { Depreciation cost }=\frac{\text { Original value of storage container }}{\text { Total life of storage container }}
$$

Again, the gross income of storage was estimated by multiplying storage quantity $(\mathrm{kg} / \mathrm{farm})$ with increased price $(\mathrm{Tk} / \mathrm{kg})$ of seed due to storage. Increased price is the difference between two prices that prevailed during seed selling and seed storing.

\section{Results and Discussion}

\section{The Project Supports}

Training: CSISA-CIMMYT project arranged training on wheat production and seed storage at household level for its collaborators before providing any sort of support from the project. The project continued its seed dissemination program for three years (2012-2014). However, 94.3\% supported farmers received training on improved wheat seed storage technique from CSISA-CIMMYT project. The rest participants received training from the district level office of Department of Agricultural Extension (DAE). Majority of the farmers (55.3\%) received training in 2013 followed by in 2014 (Table 1).

Table 1. Training organization and participating year of the supported wheat farmers

\begin{tabular}{l|cc|c|c}
\hline \multirow{2}{*}{ Particulars } & \multicolumn{4}{c}{$\%$ of responses } \\
\cline { 2 - 5 } & $\begin{array}{c}\text { Mymensingh } \\
(n=70)\end{array}$ & $\begin{array}{c}\text { Faridpur } \\
(n=70)\end{array}$ & $\begin{array}{c}\text { Rangpur } \\
(n=70)\end{array}$ & $\begin{array}{c}\text { All area } \\
(n=210)\end{array}$ \\
\hline 1. Providing organization & & & & \\
- CSISA-CIMMYT & 100 & 82.9 & 100 & 94.3 \\
$\quad$ project & & & & \\
- DAE & -- & 15.7 & -- & 5.2 \\
- IRRI & -- & 1.4 & -- & 0.5 \\
2. Participating year & & & & \\
$\quad 2012$ & 8.6 & 5.7 & 2.9 & 5.7 \\
2013 & 72.8 & 58.6 & 34.3 & 55.3 \\
2014 & 17.2 & 31.4 & 62.8 & 37.1 \\
\hline
\end{tabular}

The major training materials delivered among farmers included the improved techniques of wheat cultivation and seed storage. From the training, supported farmers learned many things regarding wheat production and storage. Majority of the farmers opined that they could learn how to produce quality seed; maintaining grain maturity, grain dryness, container's air tightness, and its 
placement. They could also know that dried grain should be kept in the container fully after proper cooling and it should be monitored several times for getting quality seed. The supported farmers mentioned that they could learn many things about wheat cultivation through participation of such a training programme. They could know the benefit of raised bed cultivation, germination test of seed, timely seed sowing, water and fertilizer management and the harmful effect of weeding wheat crop (Table 2).

Table 2. Knowledge learned by supported wheat farmers during storage training

\begin{tabular}{|c|c|c|c|c|}
\hline \multirow[b]{2}{*}{ Knowledge learned } & \multicolumn{4}{|c|}{$\%$ of responses } \\
\hline & $\begin{array}{c}\text { Mymensing } \\
\mathrm{h}(n=70)\end{array}$ & $\begin{array}{c}\text { Faridpur } \\
(n=70)\end{array}$ & $\begin{array}{c}\text { Rangpur } \\
(n=70)\end{array}$ & $\begin{array}{l}\text { All area } \\
(n=210)\end{array}$ \\
\hline \multicolumn{5}{|l|}{ A. Seed storage } \\
\hline $\begin{array}{l}\text { 1. Matured grain should be retained } \\
\text { for seed }\end{array}$ & 32.9 & 38.6 & 5.7 & 25.7 \\
\hline $\begin{array}{l}\text { 2. Wheat grain should be dried } \\
\text { properly for seed }\end{array}$ & 87.1 & 72.9 & 51.4 & 70.5 \\
\hline $\begin{array}{l}\text { 3. Seed container should be tied } \\
\text { properly }\end{array}$ & 77.1 & 80.0 & 50.0 & 69.0 \\
\hline $\begin{array}{l}\text { 4. Seed container should be placed } \\
\text { on upper place }\end{array}$ & 57.1 & 58.6 & 47.1 & 54.3 \\
\hline $\begin{array}{l}\text { 5. Container should be filled in } \\
\text { properly }\end{array}$ & 7.1 & 7.1 & 18.6 & 11.0 \\
\hline $\begin{array}{l}\text { 6. Dried grain should be kept in the } \\
\text { container after cooling properly }\end{array}$ & 17.1 & 2.9 & 11.4 & 10.5 \\
\hline $\begin{array}{l}\text { 7. Seed should be dried separately } \\
\text { from unwanted variety }\end{array}$ & 2.9 & 5.7 & -- & 2.9 \\
\hline $\begin{array}{l}\text { 8. Seed in container should be } \\
\text { monitored frequently }\end{array}$ & 1.4 & 4.3 & 1.4 & 2.4 \\
\hline \multicolumn{5}{|l|}{ B. Wheat production } \\
\hline $\begin{array}{l}\text { 1. Wheat cultivation on raised bed is } \\
\text { better compared to conventional } \\
\text { practices }\end{array}$ & -- & 7.1 & 11.4 & 6.2 \\
\hline $\begin{array}{l}\text { 2. Seed should be sown after } \\
\text { germination test }\end{array}$ & 32.9 & 30.0 & 10.0 & 24.3 \\
\hline 3. Seed should be sown timely & -- & 24.3 & 18.6 & 14.3 \\
\hline $\begin{array}{l}\text { 4. Appropriate quantity of inputs } \\
\text { (fertilizers \& irrigation) should be } \\
\text { applied timely. }\end{array}$ & -- & 12.9 & 54.3 & 22.4 \\
\hline $\begin{array}{l}\text { 5. Weed should be controlled for } \\
\text { better wheat yield }\end{array}$ & -- & -- & 2.9 & 1.0 \\
\hline $\begin{array}{l}\text { 6. Harvested wheat plant should be } \\
\text { threshed properly }\end{array}$ & -- & -- & 5.7 & 1.9 \\
\hline
\end{tabular}

Dissemination of improved wheat variety: After providing wheat production and seed storing training, CSISA-CIMMYT project disseminated a number of improved wheat varieties among supported resource poor farmers so that they could cultivate the latest released varieties of wheat. In the study areas, both supported and non-supported farmers used eight different improved wheat 
varieties. Among these varieties, BARI Gom-26 was reported to be the highest adopted variety both by supported (59\%) and non-supported farmers (52\%) farmers. Followed by BARI Gom-28, were adopted about $12 \%$ and $8 \%$ by SF and NSF, respectively. The other popular old varieties of wheat were Shatabdi and Prodip which were adopted by supported $(17 \& 18 \%)$ and non-supported $(15$ $\& 12 \%)$ farmers respectively. However, supported farmers used latest variety more than non-supported farmers (Table 3).

Most of the supported farmers (59\%) collected new and latest improved wheat varieties from CSISA-CIMMYT project, whereas about $72 \%$ non-supported farmers collected it from own source, neighbouring farmers and local market (Table 3). The findings clearly implied that most of the non-supported farmers in the study areas could cultivate new improved varieties only because of seed storage program at household level.

Table 3. Wheat variety use and sources of seeds of the sample farmers, 2013-2014

\begin{tabular}{l|c|c|c|c|c|c|c|c}
\hline \multirow{2}{*}{ Seed type and source } & \multicolumn{2}{|c|}{ Mymensingh } & \multicolumn{2}{c|}{ Faridpur } & \multicolumn{2}{c|}{ Rangpur } & \multicolumn{2}{c}{ All area } \\
\cline { 2 - 9 } & SF & NSF & \multicolumn{1}{c}{ SF } & NSF & SF & NSF & \multicolumn{1}{c}{ SF } & NSF \\
\hline 1. Variety used (\%) & $n=70$ & $n=20$ & $n=70$ & $n=20$ & $n=70$ & $n=20$ & $n=210$ & $n=60$ \\
BARI Gom-25 & 1.4 & -- & 4.3 & -- & -- & -- & 1.9 & -- \\
BARI Gom-26 & 75.7 & 80.0 & 28.6 & 20.0 & 71.4 & 55.0 & 58.6 & 51.7 \\
BARI Gom-27 & 4.3 & -- & 2.9 & -- & 8.6 & 5.0 & 5.2 & 1.7 \\
BARI Gom-28 & 22.9 & 20.0 & 1.4 & -- & 12.9 & 5.0 & 12.4 & 8.3 \\
Shatabdi & -- & -- & 34.3 & 45.0 & -- & 10.0 & 11.4 & 18.3 \\
Prodip & 2.9 & 5.0 & 40.0 & 40.0 & 2.9 & 5.0 & 15.2 & 16.7 \\
Sonalika & 1.4 & 5.0 & -- & 5.0 & 10.0 & 25.0 & 3.8 & 11.7 \\
Bijoy & -- & -- & 2.9 & -- & -- & -- & 1.0 & -- \\
2. Source of seed (\%) & & & & & & & & \\
Own & 12.9 & 20.0 & 44.3 & 50.0 & 14.3 & 20.0 & 23.8 & 30.0 \\
Neighbour/relatives & 4.3 & 20.0 & 7.1 & 25.0 & 7.1 & 20.0 & 6.2 & 21.7 \\
Local market & 11.4 & 20.0 & 15.7 & 10.0 & 4.3 & 30.0 & 10.5 & 20.0 \\
CSISA project & 74.3 & 40.0 & 25.7 & 5.0 & 75.7 & 15.0 & 58.6 & 20.0 \\
NGO & -- & -- & -- & -- & 1.4 & -- & 0.5 & - \\
DAE & -- & -- & -- & 10.0 & -- & 5.0 & -- & 5.0 \\
Dealer & -- & -- & 22.9 & 10.0 & 1.4 & 10.0 & 8.1 & 6.7 \\
\hline
\end{tabular}

Note: $\mathrm{SF}=$ Supported farmer, NSF = Non-supported farmer

Storage container used: Quality characters of wheat seed, such as seed germination, moisture content, seed color and seed-borne fungal prevalence is influenced by various factors during storage (Malaker et al., 2008). The type of storage container is one of the important factors that determine the quality of seed to a great extent. The supported farmers were provided training about the use of different types of container for seed storage. The respondent farmers stored wheat 
seed using different types of containers with different techniques. At least eight types of different storage containers were reported to use by the sample farmers. Among these devices, jute sac, plastic sac, along with poly bags and plastic/metal drum were highly used over the years by the respondent farmers.

Table 4. Average score on preference ranking for different storage devices

\begin{tabular}{l|c|c|c|c|c|c|cc}
\hline \multirow{2}{*}{$\begin{array}{l}\text { Type of } \\
\text { farmer }\end{array}$} & $\begin{array}{c}\text { Jute } \\
\text { sac }\end{array}$ & $\begin{array}{c}\text { Plastic } \\
\text { sac }\end{array}$ & $\begin{array}{c}\text { Poly } \\
\text { bag }\end{array}$ & $\begin{array}{c}\text { Plastic } \\
\text { sac }+ \\
\text { poly bag }\end{array}$ & $\begin{array}{c}\text { Jute sac } \\
+ \text { poly } \\
\text { bag }\end{array}$ & $\begin{array}{c}\text { Metal/plastic } \\
\text { drum }\end{array}$ & $\begin{array}{c}\text { Drum + } \\
\text { poly } \\
\text { bag }\end{array}$ & $\begin{array}{c}\text { Earthen } \\
\text { pot }\end{array}$ \\
\hline $\begin{array}{l}\text { A. Mymensingh } \\
\text { Supported }\end{array}$ & 1.3 & 2.7 & 3.6 & 5.3 & 5.6 & 7.1 & 7.5 & 2.8 \\
$\begin{array}{l}\text { Non-supported } \\
\text { B. Faridpur }\end{array}$ & 1.2 & 2.8 & 3.8 & 5.3 & 5.6 & 7.2 & 7.7 & 2.7 \\
Supported & 1.1 & 2.6 & 3.7 & 6.4 & 4.6 & 7.2 & 6.9 & 3.5 \\
Non-supported & 1.0 & 2.4 & 3.7 & 6.6 & 5.0 & 6.9 & 6.7 & 3.8 \\
C. Rangpur & & & & & & & & \\
Supported & 1.1 & 2.6 & 3.7 & 6.1 & 5.3 & 7.3 & 6.8 & 3.0 \\
Non-supported & 1.1 & 2.7 & 3.7 & 6.1 & 5.6 & 7.4 & 7.0 & 2.7 \\
D. All area & & & & & & & & \\
Supported & 1.1 & 2.6 & 3.7 & 6.0 & 5.2 & 7.2 & 7.1 & 3.1 \\
Non-supported & 1.1 & 2.6 & 3.7 & 6.0 & 5.4 & 7.1 & 7.1 & 3.0 \\
\hline
\end{tabular}

Note: Score ranged from 1.0 to 8.0. Scores 1 and 8 mean the lowest and highest choice/preference respectively.

The respondent farmers were asked to give preference scores that ranged from 1 to 8 considering seed quality maintenance (color and luster), cost, availability, longevity, and usability. The average score on preference ranking was found to be the highest for metal/plastic drum (7.1-7.2) for both supported and nonsupported farmers due to cost effectiveness and getting better quality seed. The next best preferred devices were metal/plastic drum+poly bag (7.1), plastic sac+poly bag (6.0), and jute sac+poly bag (4.6-5.0). The lowest preference was reported to be on using jute sac alone for both categories of farmers. In Mymensingh hub, the average score on preference ranking was the highest for metal/plastic drum + poly bag (Table 4).

Protection measures adopted: The supported farmers were provided training about different protection measures which will be adopted in the time of insectsdiseases attack. In the case of air tight container and appropriate moisture content of seed, no protection measure is needed for getting quality seed. However, more or less similar percentage of supported and non-supported farmers in the study areas took protection measures against insects. Among different protection measures, the dust/powder of Neem leaves was highly used as protection measure for both types of farmers. Usually, no cost was involved with these traditional measures. However, the average costs incurred for other less used protection measures ranged from Tk.15 to Tk. 72 (Table 5). 
Table 5. Percent responses on protective measures taken against pests during storage

\begin{tabular}{l|c|c|c|c|c|c|c|c|c}
\hline \multirow{2}{*}{ Type of protective measures } & \multicolumn{2}{|c|}{ Mymensingh } & \multicolumn{2}{c|}{ Faridpur } & \multicolumn{2}{c|}{ Rangpur } & \multicolumn{2}{c|}{ All area } & \multirow{2}{*}{$\begin{array}{c}\text { Average } \\
\text { cost }\end{array}$} \\
\cline { 2 - 8 } & SF & NSF & SF & NSF & SF & NSF & SF & NSF & (Tk/year) \\
\hline \multicolumn{1}{c}{ Sample size $(n)$} & $n=70$ & $n=20$ & $n=70$ & $n=20$ & $n=70$ & $n=20$ & $n=210$ & $n=60$ & (Tk/year \\
\hline Measure adopted $(\%)$ & 47.1 & 45.0 & 34.3 & 35.0 & 60.0 & 60.0 & 47.1 & 46.7 & -- \\
1. Neem leaf powder & 35.7 & 35.0 & 15.7 & 20.0 & -- & 20.0 & 17.1 & 25.0 & -- \\
2. Biskatali leaf powder & 4.3 & 5.0 & -- & -- & -- & 35.0 & 1.4 & 13.3 & -- \\
3. White powder & 4.3 & 5.0 & 1.4 & -- & -- & -- & 1.9 & 1.7 & 57.9 \\
4. Phostoxine & 2.9 & 5.0 & 1.4 & -- & -- & -- & 1.4 & 1.7 & 62.5 \\
5. Naphthalene & -- & -- & 7.1 & -- & -- & 10.0 & 2.4 & 3.3 & 15.3 \\
6. Insecticides & 2.9 & -- & -- & -- & -- & -- & 1.0 & -- & 16.7 \\
7. Finish powder & -- & -- & -- & 10.0 & -- & -- & -- & 3.3 & 72.1 \\
8. Others* & 2.9 & -- & 18.5 & 5.0 & -- & 5.0 & 7.2 & 1.7 & -- \\
\hline
\end{tabular}

Note: $\mathrm{SF}=$ Supported farmers, NSF $=$ Non-supported farmer, $*$ It included sand, ash, rice bran, tobacco powder

\section{Production and Distribution of Wheat Grain and Seed}

In 2013-2014, supported and non-supported farmers produced on an average 894 $\mathrm{kg}$ and $1056 \mathrm{~kg}$ of wheat of which $11.5 \%$ and $9.5 \%$ were retained for seed at household level respectively. It indicated that supported farmers produced less, but retained seed higher than that of non-supported farmers. Except Rangpur, this trend was observed at Mymensingh and Faridpur areas. The using pattern of wheat grain revealed that both supported and non-supported farmers sold more than $80 \%$ of grain and consumed the rest at household levels. Exceptions were found only in Faridpur, where household consumptions were much higher compared to other two areas.

Supported and non-supported farmers sold $64 \%$ and $52 \%$ of seed to others and used the rest amounts for their own cultivation, respectively. Farmers also reported that a small percentage $(1-4 \%)$ of seed was consumed at household level in the case of unsold or time of need (Table 6).

'Delivering improved seeds to smallholder farmers in the developing world is an efficient and sustainable method of increasing crop yields and quality' (http://www.dryingbeads.org). Both supported and non-supported small holder farmers sold seed to neighbouring farmers or relatives, other farmers at local market and fertilizer/pesticides/seed dealers. Table 7 shows that $60-61 \%$ seeds were sold to neighbouring farmers and relatives; $28-31 \%$ to other farmers at local markets; and $9-11 \%$ to fertilizer \& pesticides dealers.

However, Faridpur farmers were not found to sell any quantity to dealers. Both supported and non-supported farmers received higher price when they could sell seed to dealers and received the lowest price when they sold it to local markets. The local seed dealers in the study areas collected seed of improved variety wheat from known farmers and could sell them higher price. Again, most 
respondent farmers could sell their new variety seed to neighbouring farmers at higher price.

Table 6. Use of wheat grain and seed at farm level during Rabi season, 2013-2014

\begin{tabular}{c|c|c|c|c|c|c|c|c}
\hline \multirow{2}{*}{ Disposal pattern } & \multicolumn{2}{|c|}{ Mymensingh } & \multicolumn{2}{c|}{ Faridpur } & \multicolumn{2}{c|}{ Rangpur } & \multicolumn{2}{c}{ All area } \\
\cline { 2 - 9 } & SF & NSF & SF & NSF & SF & NSF & SF & NSF \\
\hline 1. Total production (kg) & 1007 & 1316 & 1028 & 1100 & 648 & 752 & 894 & 1056 \\
2. Use of grain (kg) & 891 & 1214 & 906 & 1000 & 577 & 656 & 791 & 956 \\
a. Sale & 763 & 1084 & 646 & 752 & 528 & 568 & 646 & 801 \\
& $(86)$ & $(89)$ & $(71)$ & $(75)$ & $(92)$ & $(87)$ & $(82)$ & $(84)$ \\
b. Consumption & 128 & 130 & 260 & 248 & 49 & 88 & 145 & 155 \\
& $(14)$ & $(11)$ & $(29)$ & $(25)$ & $(8)$ & $(13)$ & $(18)$ & $(16)$ \\
3. Use of seed (kg) & 116 & 102 & 122 & 100 & 71 & 96 & 103 & 100 \\
a. Own use & $44(38)$ & $56(55)$ & 33 & 50 & 21 & 29 & 33 & 45 \\
\multirow{2}{*}{ b. Sale } & & & $(27)$ & $(50)$ & $(30)$ & $(30)$ & $(32)$ & $(45)$ \\
c. Consumption & $3(3)$ & $1(1)$ & $6(5)$ & $3(3)$ & $2(3)$ & $4(4)$ & $4(4)$ & $3(3)$ \\
d. Gifted to others & $1(1)$ & -- & -- & -- & -- & -- & -- & -- \\
\hline
\end{tabular}

Note: $\mathrm{SF}=$ Supported farmer, NSF = Non-supported farmer

Figures in the parentheses indicate the percent of total

Table 7. Distribution pattern of sold seed and price received in 2013-2014

\begin{tabular}{|c|c|c|c|c|c|c|c|}
\hline \multirow[b]{2}{*}{ Study area } & \multicolumn{2}{|c|}{ Farmer/relatives } & \multicolumn{2}{|c|}{ Local market } & \multicolumn{2}{|c|}{ Dealer } & \multirow{2}{*}{$\begin{array}{c}\text { Total } \\
\text { quantity } \\
(\mathrm{kg})\end{array}$} \\
\hline & \begin{tabular}{|c|} 
Quantity \\
$(\mathrm{kg})$
\end{tabular} & \begin{tabular}{|c|} 
Price \\
$(\mathrm{Tk} / \mathrm{kg})$
\end{tabular} & $\begin{array}{c}\text { Quantity } \\
(\mathrm{kg})\end{array}$ & $\begin{array}{c}\text { Price } \\
(\mathrm{Tk} / \mathrm{kg})\end{array}$ & $\begin{array}{c}\text { Quantity } \\
(\mathrm{kg})\end{array}$ & $\begin{array}{c}\text { Price } \\
(\mathrm{Tk} / \mathrm{kg})\end{array}$ & \\
\hline \multicolumn{8}{|l|}{ 1. Mymensingh } \\
\hline Supported farmer & $46.2(68)$ & 41.3 & $4.6(7)$ & 39.1 & $17.4(25)$ & 40.0 & 68.2 \\
\hline Non-supported farmer & $24.8(56)$ & 37.8 & $3.5(8)$ & 37.0 & $16.0(36)$ & 35.0 & 44.3 \\
\hline \multicolumn{8}{|l|}{ 2. Faridpur } \\
\hline Supported farmer & $40.9(49)$ & 28.4 & $41.9(51)$ & 27.6 & -- & -- & 82.8 \\
\hline Non-supported farmer & $22.3(47)$ & 28.3 & $24.8(53)$ & 28.6 & -- & -- & 47.1 \\
\hline \multicolumn{8}{|l|}{ 3. Rangpur } \\
\hline Supported farmer & $32.4(68)$ & 35.7 & $14.3(30)$ & 32.8 & $1.2(2)$ & 40.0 & 47.9 \\
\hline Non-supported farmer & $47.4(75)$ & 33.4 & $15.8(25)$ & 37.5 & -- & -- & 63.1 \\
\hline \multicolumn{8}{|l|}{ 4. All area } \\
\hline Supported farmer & $39.8(60)$ & 34.3 & $20.3(31)$ & 31.1 & $6.2(9)$ & 40.0 & 66.3 \\
\hline Non-supported farmer & $31.5(61)$ & 35.1 & $14.7(28)$ & 31.6 & $5.3(11)$ & 35.0 & 51.5 \\
\hline
\end{tabular}

Note: Figures in the parentheses indicate the percentages of total quantity 


\section{Storage Device and Quantity of Seed Storage}

Table 8 revealed that supported farmers stored the highest amount of wheat seed using jute sac+poly bag in the years 2012 and 2013, although the number of users were very low. In 2014, the number of users of jute sac+poly bag increased to a great extent, but average storage quantity becomes low compared to the past two years. However, the uses of plastic/metal drum with poly bag showed an increasing trend among trained farmers over the years. In the case of nonsupported farmers, the highest amount of wheat seed was stored through plastic/metal drum over the years, although the number of users was low compared to other devices. Again, the number of users of jute sac + poly bag showed an increasing trend during 2012-14 (Table 8).

\section{Impacts of Wheat Seed Storage and Distribution Program}

The training and dissemination of improved wheat seed programme among small and marginal farmers has created a lot of socioeconomic impacts in the study areas. The perceived impacts are briefly discussed below.

Table 8. Storage devices and quantities stored in different years by wheat farmers

\begin{tabular}{|c|c|c|c|c|c|c|c|}
\hline \multirow[b]{2}{*}{$\begin{array}{l}\text { Name of storage } \\
\text { Device }\end{array}$} & \multicolumn{4}{|c|}{ Supported farmer } & \multicolumn{3}{|c|}{ Non-supported farmer } \\
\hline & $\begin{array}{l}\% \text { of } \\
\text { users }\end{array}$ & $\begin{array}{c}\text { Quantity } \\
\text { stored } \\
(\mathrm{kg})\end{array}$ & $\begin{array}{l}\text { Storage } \\
\text { duration } \\
\text { (week) }\end{array}$ & $\begin{array}{c}\text { Storage } \\
\text { loss } \\
(\mathrm{kg})\end{array}$ & $\begin{array}{l}\% \text { of } \\
\text { users }\end{array}$ & $\begin{array}{c}\text { Quantity } \\
\text { stored } \\
\text { (kg) }\end{array}$ & $\begin{array}{c}\text { Storage } \\
\text { duration } \\
\text { (week) }\end{array}$ \\
\hline Year: 2014 & $N=210$ & & & & $N=60$ & & \\
\hline 1. Jute sac + poly bag & $42(89)$ & 99.0 & 32.0 & $3(3)$ & $38(23)$ & 72.4 & 31.8 \\
\hline 2. Plastic sac + poly bag & $7(15)$ & 118.3 & 30.7 & -- & $17(10)$ & 57.5 & 31.1 \\
\hline 3. Plastic/metal drum+ poly bag & $44(92)$ & 98.2 & 30.8 & $2(1)$ & $43(26)$ & 122.9 & 35.4 \\
\hline 4. Plastic sac & $0.5(1)$ & 80.0 & 28.0 & -- & -- & -- & -- \\
\hline 5. Jute sac & $0.5(1)$ & 40.0 & 28.0 & $5(1)$ & -- & -- & -- \\
\hline 6. Poly bag & $0.5(1)$ & 35.0 & 31.0 & -- & -- & -- & -- \\
\hline 7. Earthen pot & $5(10)$ & 40.6 & 32.2 & -- & $3(2)$ & 42.5 & 32.5 \\
\hline 8. Other & $2(4)$ & 50.0 & 31.8 & -- & -- & -- & -- \\
\hline \multicolumn{8}{|l|}{ Year: 2013} \\
\hline 1. Jute sac + poly bag & $3(7)$ & 202.9 & 30.4 & -- & $12(7)$ & 42.9 & 30.7 \\
\hline 2. Plastic sac + poly bag & $27(57)$ & 94.8 & 31.9 & -- & $33(20)$ & 72.6 & 31.6 \\
\hline $\begin{array}{l}\text { 3. Plastic/metal drum+poly } \\
\text { bag }\end{array}$ & $17(36)$ & 87.9 & 31.3 & & $15(9)$ & 186.7 & 31.2 \\
\hline 4. Plastic sac & $0.5(1)$ & 40.0 & 26.0 & -- & -- & -- & -- \\
\hline 5. Poly bag & $0.5(1)$ & 60.0 & 30.0 & -- & -- & -- & -- \\
\hline 6. Earthen pot & $3(7)$ & 19.3 & 32.6 & -- & $2(1)$ & 40.0 & 33.0 \\
\hline 7. Other & $1.4(3)$ & 31.7 & 32.7 & -- & -- & -- & -- \\
\hline \multicolumn{8}{|l|}{ Year: 2012} \\
\hline 1. Jute sac + poly bag & $2(4)$ & 142.5 & 32.3 & -- & $10(6)$ & 50.0 & 31.0 \\
\hline 2. Plastic sac + poly bag & $22(47)$ & 94.8 & 31.8 & -- & $30(18)$ & 73.6 & 31.7 \\
\hline $\begin{array}{l}\text { 3. Plastic/metal drum+poly } \\
\text { bag }\end{array}$ & $12(25)$ & 58.8 & 31.04 & -- & $12(7)$ & 158.6 & 32.2 \\
\hline 4. Plastic sac & $0.5(1)$ & 30.0 & 28.0 & -- & -- & -- & -- \\
\hline 5. Earthen pot & $3(7)$ & 29.3 & 31.9 & -- & -- & -- & -- \\
\hline 6. Others & $2(4)$ & 35.0 & 33.3 & -- & $2(1)$ & 120.0 & 32.0 \\
\hline
\end{tabular}

Note: Other includes jar cane, biscuit tin, and soybean oil container

Figure in the parentheses indicates number of respondent farmer 
Increase in wheat area: CIMMYT-Bangladesh has been trying to disseminate different newly released high yielding wheat varieties along with production technologies among wheat farmers through CSISA project since 2012. Due to this effort, a substantial increase was occurred in the area under wheat cultivation in the study areas. A plenty of fallow and char lands are currently using for wheat cultivation. Again, a large group of farmers in Faridpur and Rangpur hubs become interested toward improved wheat cultivation due to the availability of improved variety seed, higher yield, less cultivation cost and financial benefit. More than $80 \%$ farmers mentioned that the seed storage program of CSISA had a positive impact on the expansion of wheat area in the study areas (Table 9). However, their statement is highly supported by the data on wheat area expansion in different CSISA-CIMMYT project Hub areas (Table 10).

Table 9. Overall impacts of wheat seed storage program in the study areas

\begin{tabular}{l|c|c|c|c}
\hline \multirow{2}{*}{ Overall impact } & \multicolumn{4}{c}{$\%$ responses } \\
\cline { 2 - 5 } & Mymensingh & Faridpur & Rangpur & All area \\
\hline Sample size $(n)$ & $n=90$ & $n=90$ & $n=90$ & $n=270$ \\
\hline $\begin{array}{l}\text { 1. Wheat area is increasing } \\
\text { 2. Farmers become financially } \\
\text { benefited }\end{array}$ & 75.6 & 77.8 & 90.0 & 81.1 \\
$\begin{array}{l}\text { 3. Improved wheat seed is now locally } \\
\text { available }\end{array}$ & 65.6 & 51.1 & 61.1 & 59.3 \\
$\begin{array}{l}\text { 4. Farmers become enthusiastic } \\
\text { towards wheat cultivation }\end{array}$ & 48.9 & 56.7 & 52.2 & 52.6 \\
$\begin{array}{l}\text { 5. Grain yield increased } \\
\text { 6. Possibility of crop damage reduced } \\
\text { and } \\
\quad \text { timely sowing increased }\end{array}$ & 57.8 & 23.3 & 18.9 & 33.3 \\
$\begin{array}{l}\text { 7. Household food security increased } \\
\text { 8. Farmers can meet up cultivation } \\
\text { cost through seed income }\end{array}$ & 11.1 & 31.1 & 34.4 & 22.2 \\
\hline
\end{tabular}

Table 10. Time series data on wheat area (ha) and their growth rates

\begin{tabular}{cccc}
\hline Year & Mymensingh & Faridpur & Rangpur \\
\hline $2011-12$ & 1322 & 51290 & 106072 \\
$2012-13$ & 1537 & 64085 & 125130 \\
$2013-14$ & 1960 & 62879 & 124971 \\
$2014-15$ & 2006 & 68841 & 154478 \\
Growth rate $(\%)$ & $14.9 * *$ & 8.6 & $11.3^{*}$ \\
\hline
\end{tabular}

Note: '**' and '*' represent significant at $5 \%$ and $10 \%$ level respectively

Source: District level DAE offices, 2015 
Increase in financial benefit: Wheat is a profitable crop in the study areas. Besides, wheat seed storage at household level is also a profitable venture to the wheat growing farmers. Therefore, a majority of the respondent farmers $(59.3 \%)$ mentioned that they become financially benefited to cultivate and storage improved variety wheat (Table 9).

Table 11 revealed that supported and non-supported farmers stored on an average $96 \mathrm{~kg}$ and $91 \mathrm{~kg}$ of seed per season respectively. The range of increased seed prices due to storage was found to be Tk.10.90 to Tk. 22.0 for supported farmers, whereas it was Tk. 9.4 to Tk. 15.8 for non-supported farmers. The higher increased price received by supported farmers might be due to improved variety and reliability. The average net returns received by supported and non-supported farmers were Tk.1210 and Tk. 1127 respectively. The non-supported farmers who stored seed in plastic/metal drum received the highest net income (Tk.1817/year) due to store higher quantities, less storage cost, and higher price of seed. Again, the supported farmers who stored seed in plastic sac+poly bag received the highest net income (Tk.1471/year) due to store higher quantities of seed.

Table 11. Profitability of wheat seed storage under different storage devices in 2014

\begin{tabular}{|c|c|c|c|c|c|c|c|}
\hline \multirow{2}{*}{ Storage device } & \multirow{2}{*}{$\mathrm{N}$} & \multirow{2}{*}{$\begin{array}{c}\text { Quantity } \\
\text { stored } \\
(\mathrm{kg} / \text { farm })\end{array}$} & \multirow{2}{*}{$\begin{array}{c}\text { Increased } \\
\text { price due } \\
\text { to } \\
\text { storage } \\
(\mathrm{Tk} / \mathrm{kg})\end{array}$} & \multirow{2}{*}{$\begin{array}{c}\text { Gross } \\
\text { income } \\
(\mathrm{Tk} / \text { farm })\end{array}$} & \multicolumn{2}{|c|}{$\begin{array}{c}\text { Cost of } \\
\text { storage device }\end{array}$} & \multirow{2}{*}{$\begin{array}{c}\text { Net } \\
\text { income } \\
\text { (Tk/farm) }\end{array}$} \\
\hline & & & & & Tk/year & $\mathrm{Tk} / \mathrm{kg}$ & \\
\hline A. Supported farmer & 212 & 95.9 & 12.92 & 1239 & 29.01 & 0.30 & 1210 \\
\hline 1. Plastic sac + poly bag & 15 & 118.3 & 12.7 & 1502 & 31.1 & 0.26 & 1471 \\
\hline 2. Jute sac + poly bag & 89 & 99.0 & 11.1 & 1099 & 32.9 & 0.33 & 1066 \\
\hline 3. Plastic/metal drum & 92 & 98.18 & 14.6 & 1429 & 26.3 & 0.27 & 1402 \\
\hline 4. Plastic sac & 1 & 80.0 & 15.0 & 1200 & 25.0 & 0.31 & 1175 \\
\hline 5. Poly bag & 1 & 35.0 & 22.0 & 770 & 25.6 & 0.73 & 744 \\
\hline 6. Earthen pot & 10 & 40.6 & 10.9 & 443 & 23.0 & 0.57 & 420 \\
\hline 7. Others & 4 & 50.0 & 18.9 & 945 & 14.4 & 0.29 & 931 \\
\hline A. Non-supported farmer & 61 & 90.5 & 12.78 & 1157 & 29.6 & 0.33 & 1127 \\
\hline 1. Plastic sac + poly bag & 10 & 57.5 & 13.9 & 799 & 31.1 & 0.54 & 768 \\
\hline 2. Jute sac + poly bag & 23 & 72.4 & 9.4 & 681 & 32.9 & 0.45 & 648 \\
\hline 3. Plastic/metal drum & 26 & 122.9 & 15.0 & 1843 & 26.5 & 0.22 & 1817 \\
\hline 4. Earthen pot & 2 & 42.5 & 17.1 & 727 & 23.0 & 0.54 & 704 \\
\hline
\end{tabular}

Note: Others included kerosene tin, edible oil jerkin, biscuit tin, etc.

Due to very small number of sample, protection cost was not considered in calculating net income 
Availability of improved variety seed: The profitability of a crop mostly depends on its productivity. Among many other factors overall wheat cultivation has been decreasing over the years due to lack of seeds of improved wheat varieties. More than half of the respondent farmers opined that the seeds of improved wheat varieties are now locally available only because of launching wheat seed storage and dissemination program through CSISA project (Table 9). Due to availability of new variety seeds, areas under new varieties have been increasing.

Enthusiasm toward wheat cultivation: It was mentioned earlier that wheat cultivation has been decreasing over the years due to various socioeconomic factors. A good section of the sampled farmers (33.3\%) in the study areas opined that they become enthusiastic towards wheat cultivation because of seed storage and dissemination program (Table 9). Some supported farmers argued that the disseminated wheat varieties had a strong demonstration effect on non-supported farmers to adopt improved wheat varieties.

Increase in productivity: The overall productivity of wheat is increased to a great extent in the study areas which was due to adoption of improved varieties and more areas were planted to improved wheat varieties. More than $22 \%$ farmers received higher yield compared to the recent past (Table 9).

Ensure timely seed sowing: In the past, wheat crop was damaged due to lack of quality seed. Besides, the sowing time also delayed because of non-availability of improved seed. Ahmed and Meisner (1996) showed that late seeding reduced the yield at the rate of $1.3 \%$ per day of delay after November 30 . Due to the seed storage and dissemination program, improved variety seeds are now locally available to the farmers. Therefore, the possibility of crop damage or late sowing of seed reduced to a great extent as mentioned by $4.8 \%$ of the sampled farmers in the study areas (Table 9).

Table 12. Income from seed storage spent on different items in 2014

\begin{tabular}{|c|c|c|c|c|}
\hline \multirow{2}{*}{ Expenditure head } & \multicolumn{4}{|c|}{ Average amount spent (Tk./HH) } \\
\hline & Mymensingh & Faridpur & Rangpur & All area \\
\hline Sample size (n) & $n=64$ & $n=72$ & $n=68$ & $n=204$ \\
\hline Average income (Tk./HH) & $3437(100)$ & $2467(100)$ & $2235(100)$ & $2694(100)$ \\
\hline 1. Met up land preparation cost & $1376(40)$ & $1399(57)$ & $852(38)$ & $1209(45)$ \\
\hline 2. Purchase food items & $733(21)$ & $190(8)$ & $363(16)$ & $418(16)$ \\
\hline 3. Purchase fertilizers & $269(8)$ & $236(10)$ & $210(9)$ & $238(9)$ \\
\hline 4. Expenses for education & $256(7)$ & $286(12)$ & $25(1)$ & $189(7)$ \\
\hline $\begin{array}{l}\text { 5. Purchase } \\
\text { instrument }\end{array}$ & -- & $7(0)$ & $588(26)$ & $199(7)$ \\
\hline 6. Settle irrigation cost & $110(3)$ & $84(3)$ & -- & $64(2)$ \\
\hline 7. Other expenses & $694(20)$ & $265(11)$ & $197(9)$ & $377(14)$ \\
\hline
\end{tabular}

Note: Figures in the parentheses indicate percent of total income 
Increase household food security: Household food security is a vast issue. However, the respondent farmers could produce higher amount of wheat through adopting improved varieties which brought food security at household level to some extent. That's why $4.1 \%$ wheat farmers claimed that their household food security increased to some extent due to improved wheat production (Table 9).

Met up cultivation cost: The income earned from seed storage was spent for different purposes. The increased income mostly spent for land preparation and buying inputs (e.g. fertilizer and irrigation) of wheat cultivation. Table 12 showed that the net income was mostly spent for land preparation and buying inputs for wheat cultivation $(56 \%)$ followed by purchase of food items $(16 \%)$, other expenses (14\%), spent for education (7\%), and buying agricultural instruments.

Other impacts: Most supported and non-supported farmers knew the method of cultivation and storage of wheat from long or near past. Their methods might be traditional to some extent. That's why the study did not find significant difference among two categories of farmers. However, a good demonstration effect of the CSISA-CIMMYT program was also found in the study areas and because of this effect many non-supported farmers could know the improved techniques of wheat cultivation and seed storage.

\section{Problems of Seed Storage}

Both supported and non-supported farmers did not face any critical problem during seed storage. During seed drying, some respondent farmers faced problem with scavenging poultry and birds. However, some of the supported farmers were found to use old variety, not rouging their wheat plot, use traditional device in seed storage, and placing seed container on ground.

\section{Conclusions and Recommendations}

\section{Conclusions}

The study has been conducted to assess the wheat seed storage systems at $\mathrm{HH}$ level, with a particular emphasis on how the poor farmers as well as the community as whole are benefited by doing the seed storage business. The wheat farmers in the study areas use eight types of storage containers and show the highest level of satisfaction towards plastic sac and plastic/metal drum along with poly bags due to cost effectiveness and better quality seed. Respondent farmers retain wheat seed at household level mainly for getting quality seed for own use, higher price, timely sowing, and higher grain yield. They sell most of their seeds to neighbouring farmers, local markets, and dealers. Wheat seed storage at household level is a profitable business to most of the respondent farmers. They can earn a reasonable income from seed storage. The farmers who store seed in plastic/metal drum receive the highest net income due to higher storage capacity, less storage cost, and higher seed price. The net income is mostly spent for the next year wheat cultivation followed by food purchase, and educational expenses. 
Due to the seed storage program, a good number of new wheat varieties have been adopted in the study areas. Most supported farmers collect new varieties from CSISA-CIMMYT project and non-supported farmers collected it from neighbouring farmers and local market. Finally, the wheat seed storage program has created a lot of socioeconomic impacts in the study areas. A substantial increase has been recorded in wheat area, wheat productivity, and financial benefit of the wheat farmers as a whole. Nevertheless, new variety wheat seed is now available in the study areas and most farmers become enthusiastic towards wheat cultivation because of this program. Respondent farmers did not face any critical problem during seed storage.

\section{Recommendations}

Respondent farmers showed the highest level of satisfaction towards plastic/metal drum due to seed quality maintenance, longevity, and cost effectiveness. But most small and marginal farmers do not have capability to buy drum. Therefore, interested small and marginal wheat farmers should be provided a plastic/metal drum with subsidized price. Finally, the study strongly recommends that the existing training and dissemination program should be extended to other new and promising areas for fostering wheat cultivation as well as improving farmers' income in Bangladesh.

Acknowledgements: The authors thankful to CSISA-CIMMYT project personnel for their invaluable cooperation during questionnaire survey. We also wish to acknowledge the financial support of CIMMYT to conduct the study. The authors also appreciate the help of many others; both individuals and institutions, during conducting this study and regret our inability to acknowledge them all individually.

\section{References}

Ahmed S.M. and C. A. Meisner. 1996. Wheat Research and Development in Bangladesh. Published by Bangladesh Australia Wheat Improvement Project and CIMMYT_Bangladesh. 55 P.

BBS. 2011. Yearbook of Agricultural Statistics of Bangladesh, Bangladesh Bureau of Statistics (BBS), Statistics and Informatics Division, Ministry of Planning, Dhaka, Bangladesh.

BBS. 2013. Statistical Yearbook of Bangladesh, Bangladesh Bureau of Statistics (BBS), Statistics and Informatics Division, Ministry of Planning, Dhaka, Bangladesh.

Page, S.L. J. 2007. Reaping the benefits: assessing the impact and facilitating the uptake of resource conserving technologies in the rice-wheat systems of the Indo-Gangetic plain. Final report submitted to DFID.

HIES. 2010. Household Income and Expenditure Survey 2010, Bangladesh Bureau of Statistics (BBS), Statistics and Informatics Division, Ministry of Planning, Dhaka, Bangladesh. 
Hussain, S. G. and A. Iqbal. 2011. Research priorities in Bangladesh agriculture. Report submitted to Bangladesh Agricultural Research Council (BARC), Farmgate, Dhaka.

Krishi Diary. 2015. Krishi Diary, 2015, Agricultural Information Services, Department of Agriculture, Khamarbari, Farmgate, Dhaka.

Malaker, P.K, I.H. Mian, K.A. Bhuiyan, A.M. Akanda and M.M.A. Reza. 2008. Effect of storage containers and time on seed quality of wheat. Bangladesh J. Agril. Res. 33(3): 469-477, September 2008.

Maswood, M.H. 2014. BADC's seed production capacity underutilised. The Daily NewAge, July 24, 2014. Last accessed: June 09, 2015 on http://newagebd.net/34264/badcs-seed-production-capacity- underutilised/ \#sthash. KGXjHiRQ.dpuf

Miah, M.A.M., T.M.B. Hossain, M.A. Matin, S. Hossain, Moniruzzaman, and R. Kumar. 2013. Assessments of the maize situation, outlook and investment opportunities to ensure food security in Bangladesh. Research report submitted to National Academy of Agricultural Research Management (NAARM), Indian Council of Agricultural Research (ICAR), Hyderabad, Andhra Pradesh, India.

Nuruzzaman. 2015. The seed marketing channels of BADC. Internship report submitted to the Department of Business Administration, Green University of Bangladesh. January, 2015. Last accessed: June 09, 2015 on http://www.slideshare.net/nuruzzamanmahd/ internship-rep

Wambugu, P. W., P. W. Mathenge, E. O. Auma and H.A.V. Rheenen. 2009. Efficacy of traditional maize (Zea mays L.) seed storage methods in Western Kenya, in African. 